\title{
Understanding Pore Formation and Structural Deformation in Carbon Spheres During KOH Activation
}

(Memahami Pembentukan Liang dan Penyahbentukan Struktur Sfera Karbon Semasa Pengaktifan KOH)

\author{
M.S. MUSA, M.M. SANAGI*, H. NUR \& W.A.WAN IBRAHIM
}

\begin{abstract}
Carbon spheres (CSS) were synthesized from sucrose by hydrothermal reaction. The synthesized materials were further activated with potassium hydroxide $(\mathrm{KOH})$ at different concentrations. The effects of $\mathrm{KOH}$ concentration on the surface area and morphology were investigated. The route for pore formation and structural deformation in carbon spheres during activation has been proposed and discussed based on micrographs and porosity trends. It was suggested that the pore formation and structural deformation phenomena were due to the intercalating power of energized $K^{+}$into the carbon. This work provides an insight of the pore formation in carbon spheres for the development of adsorbents as well as for the understanding of the structural deformation of such materials at higher КОН concentrations.
\end{abstract}

Keywords: Carbon spheres; hydrothermal reaction; KOH activation; morphology; surface area

\section{ABSTRAK}

Sfera karbon (CSS) telah disintesis daripada sukrosa dengan tindak balas hidroterma. Bahan yang telah disintesis telah diaktifkan dengan kalium hidroksida (КОН) pada kepekatan berbeza. Kesan kepekatan КОН terhadap luas permukaan dan morfologi telah dikaji. Laluan bagi pembentukan liang dan penyahbentukan struktur sfera karbon semasa pengaktifan telah dicadang dan dibincangkan berdasarkan mikrograf dan tren keliangan. Dicadangkan iaitu fenomena pembentukan liang dan penyahbentukan struktur tersebut adalah disebabkan oleh kuasa tujahan K+ yang bertenaga ke dalam karbon. Kerja ini memberikan penerangan tentang pembentukan liang di dalam sfera karbon bagi pembangunan bahan penjerap dan juga pemahaman tentang penyahbentukan struktur bahan berkenaan pada kepekatan KOH yang tinggi.

Kata kunci: Luas permukaan; morfologi; pengaktifan КОН; sfera karbon; tindak balas hidroterma

\section{INTRODUCTION}

Carbon spheres (CSs) are spherical form of carbon having either semi-crystalline or crystalline structure with solid, hollow or core shell morphology. The spherical carbons include carbon blacks, carbon onions and carbon microbeads (Deshmukh et al. 2010). Many findings have been published in the literature related to the synthesis and activation of carbon spheres (Deshmukh et al. 2010; Li et al. 2011). These techniques include shock compression technique (Niwase et al. 2002), high temperature pyrolysis, chemical vapour deposition (Qian et al.2004), hydrothermal treatment (Sevilla \& Fuertes 2009; Wang et al. 2001), arc discharge (Qiao et al. 2006) and thermal plasma processes (Okuno et al. 2004) have been in practice for the synthesis of carbon spheres. Among these methods, hydrothermal approach is the simplest in terms of operation due to its mild reaction condition requirements (Hu et al. 2008).

Activated form of carbon spheres was found to possess properties like high specific areas, uniformity, high thermal stability and excellent conductivities which make them useful as catalyst support, adsorbents and super capacitors. They are also used in hydrogen storage (Li et al. 2011; Wang et al. 2001) and drug delivery. A frequently applied method to obtain carbons with high surface area and narrow micropore distribution is through chemical activation usually using alkaline hydroxides as activating agents due to their ability to activate carbon generated from many kinds of carbonaceous precursors like coals, chars and fibres (Lillo-Rodenas et al. 2003; Lozano-Castello et al. 2001).

Pores are formed in CSs when they are activated with $\mathrm{KOH}$, but activation carried out at high $\mathrm{KOH}$ concentration may result in structural distortion of the CSs. There are basically two approaches in the activation process of carbon spheres using alkali-metal hydroxides and each depends on the physical state of the activating agent (solid or liquid). Mechanism of pore formation by physical mixing of solid activating agent like $\mathrm{KOH}$ pellet with carbon via grinding (solid-solid reaction) has been proposed to have occurred through reduction of $\mathrm{KOH}$ to K-metal and oxidation of carbon to carbonate (RaymundoPinero et al. 2005). However, no explanation is reported on the routes leading to the structural deformation of the sphere shape during the process especially when the activating agent is in liquid form (solid-liquid reaction). Apart from pure carbon, pore formation mechanism in other inorganic material (magnesium carbonate Upsalite) has also been reported by Frykstrand et al. (2014). 
This work described for the first time the phenomenon of structural deformation of CSs during $\mathrm{KOH}$ activation specifically when the activating agent is in liquid form (aqueous solution). The routes for the pore formation and structural deformation were proposed based on the intercalation ability of the potassium ion into the material.

\section{MATERIALS AND METHODS}

Carbon spheres used in this study were hydrothermally synthesized from sucrose (Sigma-Aldrich, 99.5\%; EMD Chemicals, ACS grade). Other reagents: absolute ethanol (99.9\% Scharlab S.L, Spain), potassium hydroxide pellets (Darmstadt, Germany) were of analytical grade and used without further purification. Deionized water used was prepared in a Milli-Di Millipore machine (SAS 67120 Molshem, France).

\section{SYNTHESIS OF ACTIVATED CARBON SPHERES}

Fifty $\mathrm{mL}$ of $0.8 \mathrm{~mol} / \mathrm{L}$ sucrose solution was prepared for the hydrothermal synthesis of CSs. A detail of the experimental procedure was described elsewhere ( $\mathrm{Li}$ et al. 2011). The prepared solutions were further activated at different $\mathrm{KOH}$ concentrations $(0.1,1.5,2.0,2.5$ and $2.75 \mathrm{~mol} / \mathrm{L})$ through pyrolysis. In each case, $0.15 \mathrm{~g}$ of CSs was mixed with 2.0 $\mathrm{mL}$ of the prepared $\mathrm{KOH}$ aqueous solution in a combustion boat and continued as reported by $\mathrm{Li}$ et al. (2011). The pyrolysis was carried out at $450^{\circ} \mathrm{C}$ for $1 \mathrm{~h}$.

\section{CHARACTERIZATION}

The morphology and size of the CSs were determined on a JEOL JSM-6390LV scanning electron microscope (SEM). The Brunauer-Emmett- Teller (BET) surface area of each sample was measured using $\mathrm{N}_{2}$ adsorption-desorption isotherms after degassing at $110^{\circ} \mathrm{C}$ using metrometrics ASAP 2010 surface area analyser (Georgia, USA).

\section{RESULTS AND DISCUSSION}

\section{EFFECT OF KOH CONCENTRATION ON THE SURFACE} AREA OF ACTIVATED CARBON

An increase in $\mathrm{KOH}$ concentration improves the number of pores formed during chemical activation which leads to an increase in the surface area. Table 1 provides the textural properties of CSs before and after activation. It can also be deduced from the table that apart from ACS-2.0 with pore size of $1.72 \mathrm{~nm}$, the materials developed are mesoporous in nature (pore size between 2 and $50 \mathrm{~nm}$ ).

However, all the $\mathrm{N}_{2}$ adsorption-desorption isotherms (Figures 1(a)-1(d)) correspond to type I isotherm where high uptakes are observed at relatively low pressures due to the narrow pore width and high adsorption potential. Type I sorption isotherm is usually obtained on microporous materials (Lowell et al. 2004). These two pieces of information confirmed that with the exception of ACS2.0 which is almost purely microporous, all the other activated carbon spheres consisted of micropore/mesopore structures.

Other evidences to support the existence of micropore structure in the activated carbon spheres is firstly the exhibition of open loop hysteresis in all the sorption isotherms (Figures 1(a)-1(d)) which looks more of $\mathrm{H} 4$ hysteresis and secondly a positive Y-intercept in their t-plots. The H4 hysteresis is often associated with narrow-slit pores including pores in the micropore region (Lowell et al. 2004) and a positve Y-intercept in t-plot is an indication of the presence of micropore volume/area in the sample.

Table 1 has clearly indicates very small BET surface area $\left(7.8832 \mathrm{~m}^{2} / \mathrm{g}\right)$ and a negative value of micropore area $\left(-0.6149 \mathrm{~m}^{2} / \mathrm{g}\right)$ against non-activated carbon spheres (CS-0.00). The small BET surface area may be attributed to the limited number of pores present in the sample since it has not been chemically activated. Furthermore, the negative value of the micropore area revealed that there is no micropore volume/area in the sample and therefore all the limited pores present were within the mesopore region. This assertion can be supported by observing a closed loop isotherm plot (Figure 1(e)) which is usually found in mesoporous materials and secondly the fact that a negative Y-intercept was noticed in the t-plot.

\section{ENVISAGED ROUTE OF PORE FORMATION DURING KOH ACTIVATION OF CARBON SPHERES}

SEM images coupled with porosity trend of KOH activated carbon spheres at different concentrations were used to investigate the route of pore formation and structural deformation during chemical activation. In this study, a

TABLE 1. Textural properties of CSs before and after activation at different $\mathrm{KOH}$ concentrations

\begin{tabular}{lcccc}
\hline Sample & $\begin{array}{c}\text { BET surface area } \\
\left(\mathrm{m}^{2} / \mathrm{g}\right)\end{array}$ & $\begin{array}{c}\text { Micropore area } \\
\left(\mathrm{m}^{2} / \mathrm{g}\right)\end{array}$ & $\begin{array}{c}\text { Total pore volume } \\
\left(\mathrm{cm}^{3} / \mathrm{g}\right)\end{array}$ & $\begin{array}{c}\text { Pore size } \\
(\AA)\end{array}$ \\
\hline CS-0.00 & 7.88 & -0.61 & 0.009 & 44.89 \\
ACS-0.10 & 151.89 & 121.61 & 0.078 & 20.41 \\
ACS-1.50 & 165.43 & 135.13 & 0.091 & 22.05 \\
ACS-2.00 & 308.10 & 258.36 & 0.133 & 17.21 \\
ACS-2.75 & 552.33 & 444.17 & 0.303 & 21.96 \\
\hline
\end{tabular}

ACS $=$ Activated carbon spheres and the attached values indicate $\mathrm{KOH}$ concentrations in mol/L .

While CS- $0.00=$ non-activated carbon spheres 

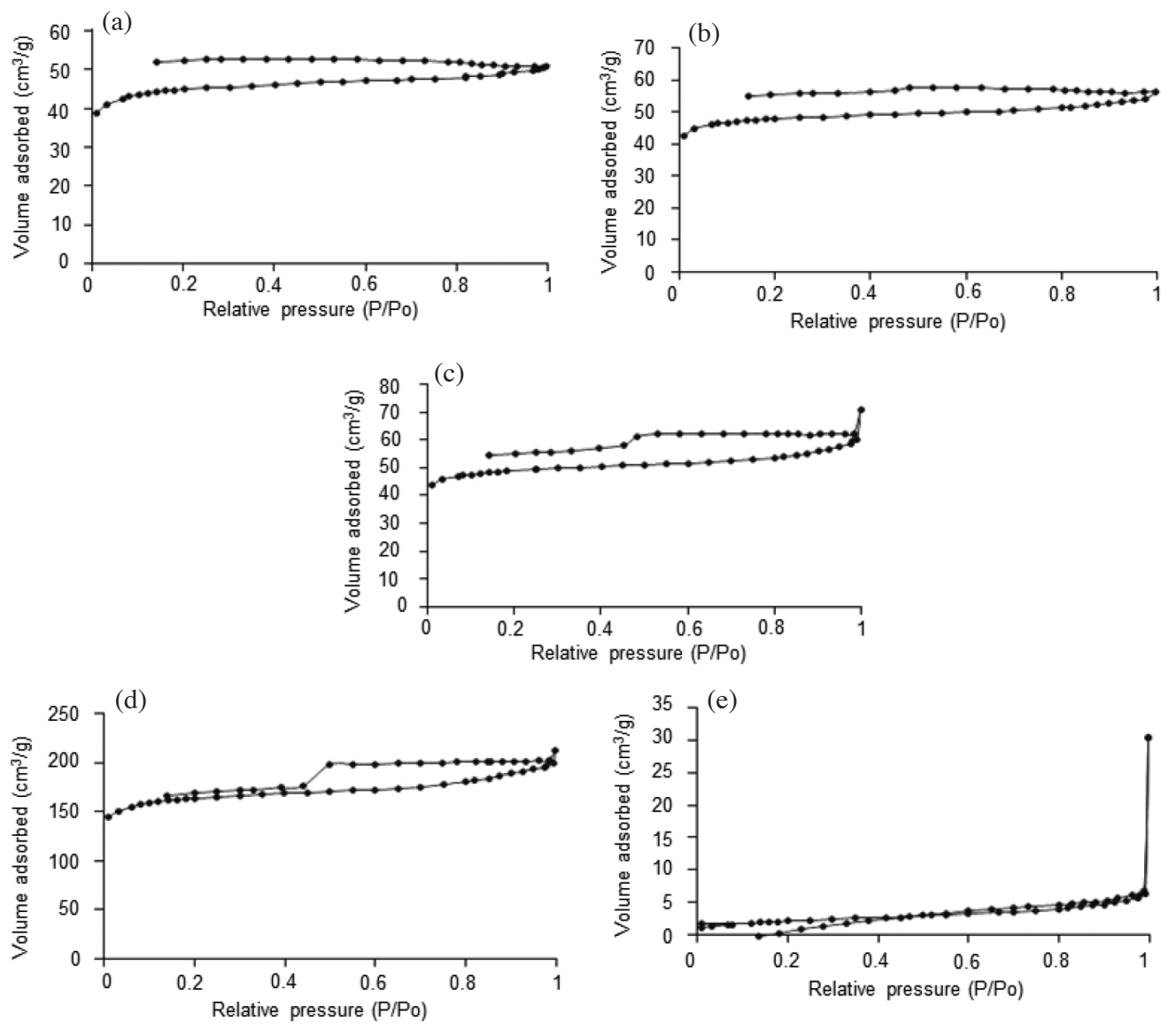

FIGURE 1. $\mathrm{N}_{2}$ adsorption-desorption isotherms for ACS-0.10 (a), ACS-1.50

(b), ACS-2.0 (c), ACS-2.75 (d) and CS-0.0 (e)

solid-liquid activation reaction using $\mathrm{KOH}$ aqueous solution and carbon spheres is considered.

The first step is dissociation of $\mathrm{KOH}$ in water according to the equation.

$$
\mathrm{KOH}_{(\mathrm{s})} \longrightarrow \mathrm{K}_{(\mathrm{aq})}^{+}+\mathrm{OH}_{(\mathrm{aq})}^{-}
$$

Alkali metal ions are known to possess an intercalating power into different materials (Inagaki \& Tanaike 2001). In aqueous solution, potassium ions $\left(\mathrm{K}^{+}\right)$are randomly spread and free to move. During chemical activation, these ions are heated and become energized $\left({ }^{*} \mathrm{~K}^{+}\right)$which then considerably intercalate into the carbon spheres to form the pores as demonstrated in Figure 2.

\section{EFFECT OF KOH CONCENTRATION ON THE MORPHOLOGY OF CARBON SPHERES}

SEM micrographs have shown that structural deformation on the CSs depends on the $\mathrm{KOH}$ concentration as observed in Figure 3(a)-3(e).

At $0.1 \mathrm{M} \mathrm{KOH}$ (Figure 3(a)), the morphology virtually remains unchanged. The stability of structure observed was possibly as a result of very few energized $\mathrm{K}^{+}$at low $\mathrm{KOH}$ concentration which might have been used up in forming the pores.
However, at concentrations of 1.5 and $2.0 \mathrm{~mol} / \mathrm{L}$ $\mathrm{KOH}$, slight deformations were noticed on the morphology of the CSs (Figure 3(b) and 3(c)). The slight structural deformation observed at this concentration is associated to the presence of more energized potassium ions $\left(* \mathrm{~K}^{+}\right)$ than in the previous case (Figure 3(a)). In this case, the few excess $* \mathrm{~K}^{+}$probably rub the CSs at their surfaces thereby causing the defect. At relatively higher concentration of $2.5 \mathrm{M} \mathrm{KOH}$ (Figure 3(d)), the surfaces become rough which could be due to higher number of excess $* \mathrm{~K}^{+}$that consequently scrape and remove some parts of the CSs at the surface. When the concentration was increased above $2.5 \mathrm{M} \mathrm{KOH}$, the structure was found to collapse entirely (Figure 3(e)) and the foreseen route of such structural collapse is envisaged in section 3.4.

\section{PROPOSED ROUTE OF STRUCTURAL COLLAPSE OF CSS AT HIGHER KOH CONCENTRATION}

At higher $\mathrm{KOH}$ concentration (2.75 $\mathrm{M}$ and above), the number of potassium ions becomes large and therefore, there is high probability that more than one energized potassium ion $\left(* \mathrm{~K}^{+}\right)$can penetrate the CSs through the same point. Each penetrating $* \mathrm{~K}^{+}$advances the depth of the pore further which consequently results into the creation of through pores (Pores that open channel at one 

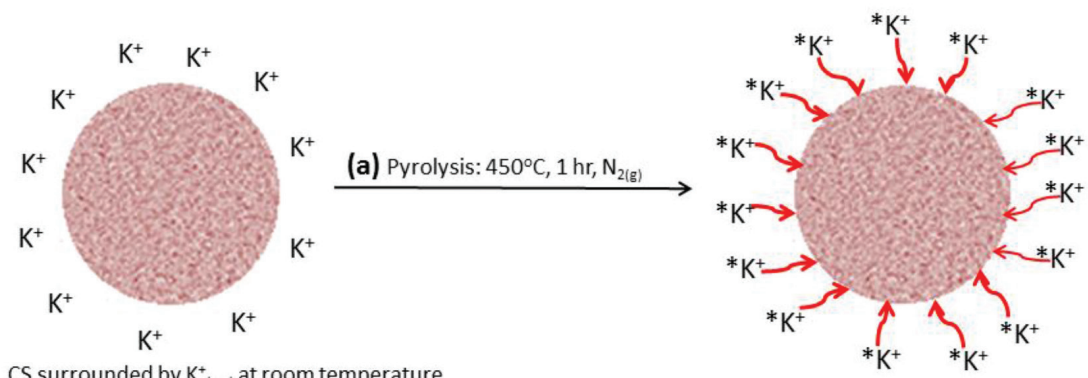

CS surrounded by $\mathrm{K}_{(\mathrm{aq})}^{+}$at room temperature
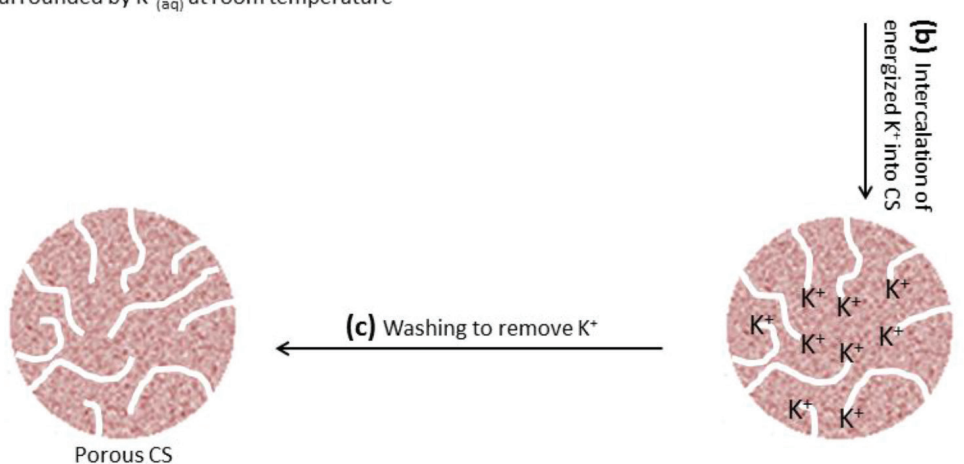

(c) Washing to remove $\mathrm{K}^{+}$

FIGURE 2. Illustration of pore formation processes at lower $\mathrm{KOH}$ concentrations $(<2.0 \mathrm{M})$ : Carbon sphere surrounded by free $\mathrm{K}^{+}$in aqueous solution (a), penetration of energized potassium ion,

$* \mathrm{~K}^{+}$into the CS (b), removal of the ions to produce porous CS (c)
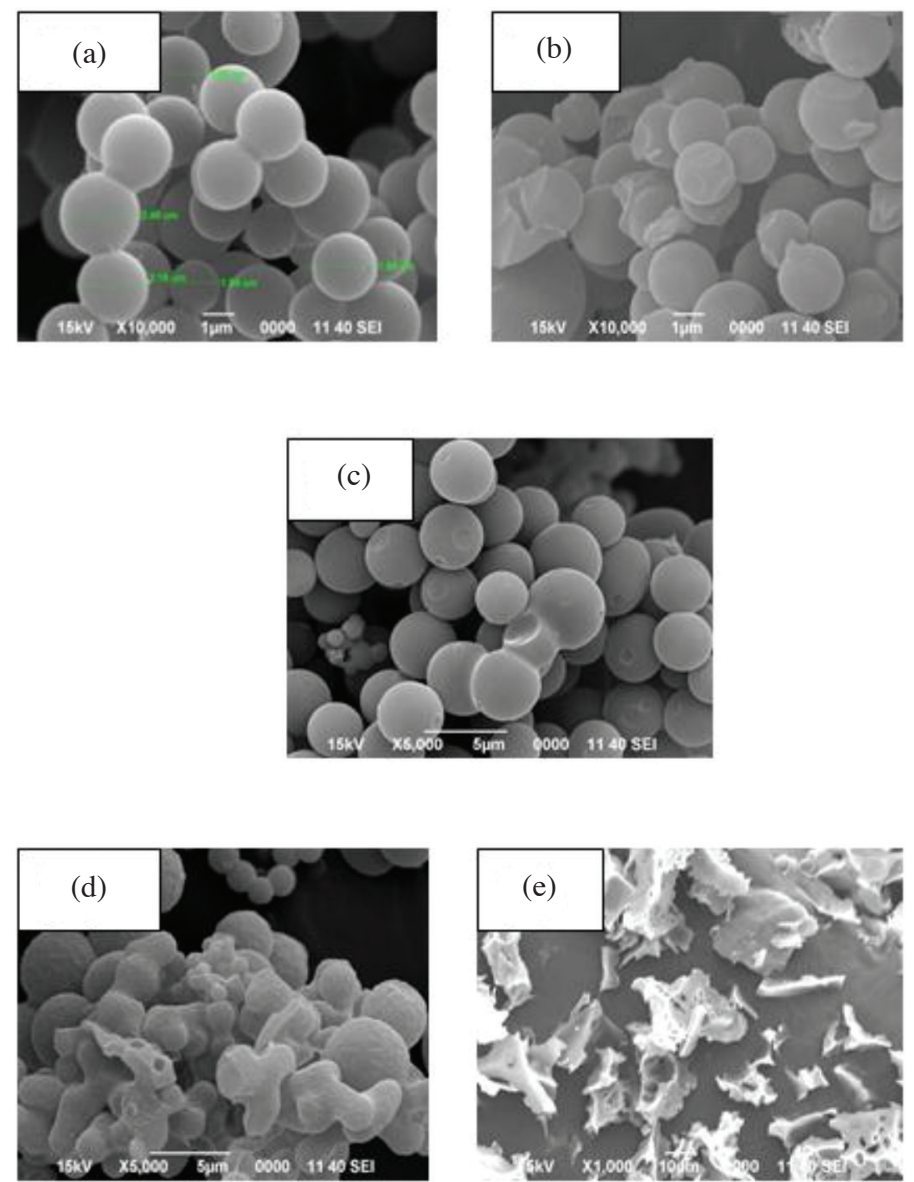

FIGURE 3. Micrographs of ACSs at $0.1 \mathrm{M}(\mathrm{a}), 1.5 \mathrm{M}(\mathrm{b}), 2.0 \mathrm{M}$

(c), $2.5 \mathrm{M} \mathrm{KOH}(\mathrm{d})$ and $2.75 \mathrm{M} \mathrm{KOH} \mathrm{(e)}$ 


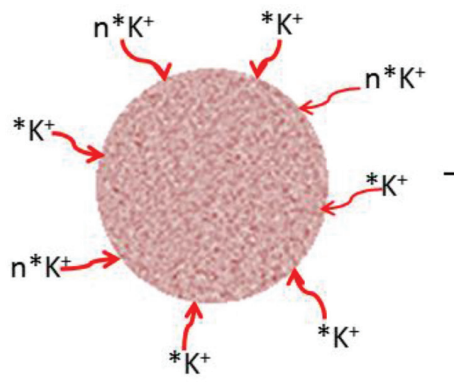

(a) Energized $\mathrm{K}^{+}$striking the CS

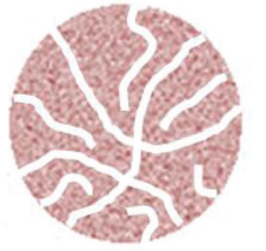

(b) Formation of through and blind pores

(c) Collapsing of CS due to interconnectivity/tortuosity of through pores

FIGURE 4. Pore formation and structural collapse of CSs at higher $\mathrm{KOH}$ concentrations (above 2.5M): Penetration/intercalation of $* \mathrm{~K}^{+}$into the CS (a); Formation of through and blind pores (b); Distortion of the sphere structure by the interconnecting through pores (c)

location, extend into particle and re-emerge at different location). Due to the interconnectivity/tortuosity properties of through pores, development of large number of such pores can distort to a greater extent, the binding forces holding a unit structure of carbon sphere and this could be the possible cause of the total collapse of the spherical structure. The phenomenon is demonstrated in Figure 4.

\section{CONCLUSION}

This study demonstrated that the surface area and structure of activated carbon spheres depend on the $\mathrm{KOH}$ concentration during activation. Optimum activation was achieved at $\leq 2.0 \mathrm{~mol} / \mathrm{L} \mathrm{KOH}$ producing micro- and or mesoporous CSs (1.7 - $4.5 \mathrm{~nm}$ pore size) with retained morphologies and appreciable BET surface areas. Pore formation and structural deformation were observed due to the intercalation of energized $\mathrm{K}^{+}$into the carbon and interconnectivity of through pores. This work established a deeper understanding of pore formation as well as structural deformation of carbon spheres during $\mathrm{KOH}$ activation.

\section{ACKNOWLEDGEMENTS}

The authors would like to thank Universiti Teknologi Malaysia and the Ministry of Education Malaysia (MOE) for the financial supports through Research Grant Vote Number Q.J130000.2526.03H79 and Bayero University, Kano, Nigeria for studentship for M.S. Musa.

\section{REFERENCES}

Deshmukh, A.A., Mhlanga, S.D. \& Coville, N.J. 2010. Carbon spheres. Material Science and Engineering Reports 70: 1-28.

Frykstrand, S., Forsgren, J., Mihranyan, A. \& Strømme, M. 2014. On the pore forming mechanism of Upsalite, a microand mesoporous magnesium carbonate. Microporous and Mesoporous Materials 190: 99-104.

Hu, B., Yu, S., Wang, K., Liu, L. \& Xu, X. 2008. Functional carbonaceous materials from hydrothermal carbonization of biomass: An effective chemical process. Dalton Transactions 40: 5414-5423.

Inagaki, M. \& Tanaike, O. 2001. Determining factors for the intercalation into carbon materials from organic solutions. Carbon 39: 1083-1090.

Li, M., Li, W. \& Liu, S. 2011. Hydrothermal synthesis, characterization, and $\mathrm{KOH}$ activation of carbon spheres from glucose. Carbohydrate Research 346: 999-1004.

Lillo-Ro’'Denas, M.A., Cazorla-Amoro'S, D. \& Linares-Solano, A. 2003. Understanding chemical reactions between carbons and $\mathrm{NaOH}$ and $\mathrm{KOH}$ : An insight into the chemical activation mechanism. Carbon 41: 267-275.

Lowell, S., Shields, J.E., Thomas, M.A. \& Thommes, M. 2004. Characterization of Porous Solids and Powders: Surface Area, Pore Size and Density. 4th ed. Dordrecht: Springer Publishers.

Lozano-Castello, D., Lillo-Ródenas, M.A., Cazorla-Amorós, D. \& Linares-Solano, A. 2001. Preparation of activated carbons from Spanish anthracite I. Activation by KOH. Carbon 39: 741-749.

Niwase, K., Homae, T., Nakamura, K.G. \& Kondo, K. 2002. Generation of giant carbon hollow spheres from $\mathrm{C} 60$ fullerene by shock-compression. Chemical Physics Letters 362: 47-50. 
Okuno, H., Grivei, E., Fabry, F., Grunberger, T.M., GonzalezAguilar, J., Palnichenko, A., Fulcheri, L., Probst, N. \& Charlier, J.C. 2004. Synthesis of carbon nanotubes and nanonecklaces by thermal plasma process. Carbon 42: 2543-2549.

Qian, H., Han, F., Zhang, B., Guo, Y., Yue, J. \& Peng, B. 2004. Non-catalytic CVD preparation of carbon spheres with a specific size. Carbon 42: 761-766.

Qiao, W.M., Song, Y., Lim, S.Y., Hong, S.H., Yoon, S.H., Mochida, I. \& Imaoka, T. 2006. Carbon nanospheres produced in an arc-discharge process. Carbon 44: 187-190.

Raymundo-Piñero, E., Azaïs, P., Cacciaguerra, T., CazorlaAmorós, D., Linares-Solano, A. \& Béguin, F. 2005. KOH and $\mathrm{NaOH}$ activation mechanisms of multiwalled carbon nanotubes with different structural organisation. Carbon 43: 786-795.

Sevilla, M. \& Fuertes, A.B. 2009. Chemical and structural properties of carbonaceous products obtained by hydrothermal carbonizaon of saccharides. Chemistry A European Journal 15(16): 4195-4203.

Wang, Q., Li, H., Chen, L. \& Huang, X. 2001. Monodispersed hard carbon spherules with uniform nanopores. Carbon 39: 2211-2214.
Mohammed Salisu Musa, Mohd Marsin Sanagi* \& Wan Aini Wan Ibrahim

Department of Chemistry, Faculty of Science

Universiti Teknologi Malaysia

81310 UTM Johor Bahru, Johor

Malaysia

Mohd Marsin Sanagi* \& Hadi Nur

Ibnu Sina Institute for Fundamental Science Studies,

Nanotechnology Research Alliance

Universiti Teknologi Malaysia

81310 UTM Johor Bahru, Johor

Malaysia

*Corresponding author; email: marsin@kimia.fs.utm.my

Received: 18 August 2014

Accepted: 30 October 2014 